http://dx.doi.org/10.12775/szhf.2021.017

JOANNA USAKIEWICZ

University of Bialystok, Poland

E-MAIL: J.USAKIEWICZ@UWB.EDU.PL

ORCID: 0000-0003-2767-4024

\title{
Eleonora Ziemięcka, the First Polish Woman Philosopher: On the Essence and the Role of Philosophical Thinking
}

\begin{abstract}
Eleonora Ziemięcka (1815-1869) is considered the first Polish woman philosopher. She represented Christian philosophy. She expressed her philosophical views most profoundly in a work Zarysy filozofii katolickiej $w$ czterech pogladach zawarte [Outlines of Catholic Philosophy Included in Four Views]. She also spoke about the education of women, to which she devoted the work Myśli o wychowaniu kobiet [Thoughts on Education of Women]. In the text Myśli o filozofii [Thoughts on Philosophy], published in 1840, she presented her thoughts on the essence and role of philosophy. It is this issue that is discussed in this article.
\end{abstract}

Keywords: Eleonora Ziemięcka, Polish woman philosopher 
Eleonora Ziemięcka, née Gagatkiewicz, $\left(1815^{1}-1869\right)$ is thought to be the first Polish woman philosopher. She was also a publicist and a founder of Pielgrzym [The Pilgrim] (Warsaw 1842-1846): the magazine that presented the Catholic philosophical thought and was aimed at reviving Polish Catholicism. She expressed her opinions on women's education and voiced her reflections most profoundly in a work entitled Myśli o wychowaniu kobiet [Thoughts on Education of Women] (Warsaw 1843). She discussed philosophical issues in numerous articles that often were meant to popularize the science. A systematic lecture of her philosophical views may be found in her work Zarysy filozofii katolickiej w czterech pogladach zawarte [Outlines of Catholic Philosophy Included in Four Views] (Warsaw 1857). ${ }^{2}$ Her latter Studia Eleonory Ziemięckiej [Studies by Eleonora Ziemięcka] (Vilnius 1860) are also crucial to understand her beliefs.

As for ontology, Ziemięcka refers to Christian creationism - God, in his infinite might, created everything out of nothingness as he could do it, not as he had to. Thus, the world is totally God-dependent. Also, in relation to his perfection, the world is imperfect; each being, however, has a perfection of its own. Within his justice and goodness, God sets the aim and the order of the world. The human being is a composition of the spirit and the body. The human spirit includes the following elements: the existence, the spirituality,

1 The literature on Eleonora Ziemięcka provides two years of her birth: 1815 and 1819. The latter one may be even found more often. However, I accept 1815 after Dorota Samborska-Kukuć, who in her article "Z genealogii rodu i biografii Eleonory z Gagatkiewiczów Ziemięckiej” (Ruch Literacki LX 4, 355 (2019): 475-486) presents the content of her Act of Birth found in the National Archive in Warsaw. More information in Polish on her life is also to be found in the article. For the Ziemięcka's life, work, and views see also e.g.: 700 lat myśli polskiej. Filozofia i myśl społeczna w latach 1831-1864, collective work (Warszawa: Państwowe Wydawnictwo Naukowe, 1977), 674; Jan Ryszard Błachnio, Poglady filozoficzne Eleonory Ziemięckiej na tle sporów ideowych połowy XIX wieku (Bydgoszcz: Wydawnictwo Uczelniane WSP w Bydgoszczy, 1997) (that monograph includes also an index of her works by and a bibliography of works connected with Ziemięcka); entry: "Ziemięcka Eleonora”, in: Encyklopedia Filozofii Polskiej, collective edition (Lublin: Polskie Towarzystwo Tomasza z Akwinu, 2011), vol. 2, 886-887.

2 The four views describe: the world of nature, the world of morals, which is the world of reason and will, the world of divine revelation, and the world of society; see Eleonora Ziemięcka, Zarysy filozofii katolickiej w czterech poglądach zawarte (Warszawa: S. Orgelbrand, 1857). 
which is the essence, as well as some powers, the most important of which are the reason and the will, of which it is the reason that seeks for the truth and the will that yearns for the good.

Ziemięcka's epistemology is based on the thesis holding that it is God who is the ultimate cause of human cognition. Both the body and the spirit take part in the cognitive process and the path goes from experience to an intellective thought. Those are also cognitive powers and religious beliefs themselves that may serve as subjects of intellective reflections. Human beings know as much about God as he wants to show them and they may see as much of the truth as they are allowed to. Knowing God is based not only on reason but also on love. By subordinating everything to the faith, Ziemięcka does not reject the need to get intellective or scientific knowledge: there is a natural world order that we learn by our reason and there is a supernatural world order that is granted by the revelation.

What makes a crucial issue for Ziemięcka is morality. She understands it as the Christian morality based on the two orders: the nature and the revelation. She believes that there is one moral law for all humans. It is God that is the aim and the supreme good and both the natural and the revealed laws originate from him. God, thus, is the ultimate criterion for the truth and every value. Human beings have got a natural attraction to good in their hearts. God's Providence supports him in his actions. Those are the revelation and the faith that reinforce the reason that induces the will and makes it independent from impulses so that a virtuous life can be led.

Ziemięcka's thought was most visibly influenced by Thomas Aquinas, however, some inspirations by Augustine of Hippo may also be noticed. Of modern philosophers, she valued René Descartes, Nicolas Malebranche, and Immanuel Kant. She felt particularly attracted to German idealism and the philosophy by Georg Wilhelm Friedrich Hegel. She moved, however, from her initial fascination towards fierce criticism of Hegel's views, believing that, by their nature, they formed a system that contradicted Christianity and supported pantheism understood as "the deification of the world". Ziemięcka first got familiarized with Hegel's philosophical system by his Polish supporters who published in Kwartalnik Naukowy [The Scientific Quarterly] issued in Cracow and edited by Antoni Zygmunt Helcel (1808-1870). During her stay in Cracow, she might also have heard some lectures by Hegel's disciple: 
Józef Kremer (1806-1875), who dealt mostly with the issues of ethics and the history of art from a philosophical point of view. ${ }^{3}$ It should be noticed here that Hegelianism presented in the circles of Kwartalnik Naukowy was strongly connected with the main goal of the magazine, which was implementing important social objectives such as educating the Poles and spreading the love of philosophy in them. And the issues of education and society had been close to Ziemięcka ever since the beginning of her activity as a writer. On the other hand, it was important that Hegel himself stressed the Christian nature of his system. Hence, Ziemięcka kept on reading and studying writings by Hegel and Friedrich Wilhelm Joseph von Schelling later, during her stay in Dresden. After some time, as she got more familiarized with German idealism, her enthusiasm for the thought faded, which was expressed in her text entitled Myśli o filozofii [Thoughts on Philosophy] published in 1841 in Biblioteka Warszawska [The Warsaw Library] and written, as it is informed by the author, in June $1840 .{ }^{4}$ The text is to be the main point of reference in my considerations on Ziemięcka's understanding the essence and the role of philosophy. I am to take it as her declaration of her own philosophical stance.

In Ziemięcka's opinion, the philosophical stance is determined by the aim to which philosophers aspire in their considerations. Ever since the beginning, philosophers have defined the scope of their interest, differentiating it from other human activities and setting their own place in human society. As the task of philosophy, they have set contemplating the whole of being, which was aimed at knowing, understanding, and explaining the world. They have indicated the desire to know as a natural need by the human spirit. They have trusted that the truth can be revealed. From the beginning, they have also connected philosophical reflection with defined moral views and

3 See 700 lat myśli polskiej. Filozofia i myśl społeczna w latach 1831-1864, 23 and further, 182 and further. See also Jan Ryszard Błachnio, Idealizm niemiecki i filozofia narodowa w polskiej myśli chrześcijańskiej lat 1831-1863 (Bydgoszcz: Wydawnictwo Uczelniane WSP w Bydgoszczy, 1994).

4 See Eleonora Ziemięcka, "Myśli o filozofii", Biblioteka Warszawska. Pismo poświęcone naukom, sztukom i przemysłowi, vol. 2 (1841): 388-422. A fragment of the text has also been published in 700 lat myśli polskiej. Filozofia i myśl społeczna w latach 1831-1864, 675-679; the whole text has been published in: Kronos 3 (46) (2018): 258-277. The same issue of the Kronos magazine includes a comprehensive article on Ziemięcka: Damian Włodzimierz Makuch, "Przeciwko pozorom rozumu. Eleonora Ziemięcka i opozycje myśli nowoczesnej”. 
lifestyles. The classic understanding of philosophy, viewed as a rational reflection on the world, of the human, of the absolute, aimed at revealing the truth, is expressed by Ziemięcka in several ways. When stressing the knowledge of self and the knowledge of God, she writes that philosophy is "a science attempting to study the supreme metaphysical questions"; ${ }^{5}$ it is "musing of individual spirits over their natures and their attitudes towards God"; 6 it is "a subjective action of the reason towards examining and defining its own nature"; 7 it is "a work of the reason itself". ${ }^{8}$ By referencing to the Greeks, she indicates that the supreme and, actually, the only one achievable knowledge for humans is connected with knowing themselves. ${ }^{9}$ Thus, she refers to the ancient adage "know thyself" that has been repeated by philosophers for ages. ${ }^{10}$ Ziemięcka also describes philosophy as "exploring the supreme aspects of one's self, [which] results from a conversation with oneself, [which] is an internal consideration". ${ }^{11}$ Some inspirations by Augustine of Hippo may be seen here, as for instance by his known sentence: "Do not wander far and wide but return into yourself; deep within man there dwells the truth". ${ }^{12}$ When writing on philosophical inquiries, Ziemięcka also indicates that what is important is "hearing the inner voice". ${ }^{13}$ Her Myśli o filozofii [Thoughts on Philosophy] includes also an explanation of philosophy in reference to the

${ }^{5}$ Nauka usiłująca zbadać najwyższe zagadnienia metafizyczne; Ziemięcka, "Myśli o filozofii": 407. [All citations from Ziemięcka in this article are own translations of the Polish originals.]

${ }_{6}$ Dumanie ducha indywidualnego nad swoja natura $i$ swym stosunkiem do Boga; ibid., 408.

7 Podmiotowe działanie rozumu ku zbadaniu i określeniu swej natury; ibid., 414.

8 Dzieło samego rozumu; ibid., 416.

9 See ibid., 415.

10 See e.g.: Plato, Charmides, 164d; Cicero, Tusculan Disputations, 1, 22, 52; Augustine of Hippo, On the Holy Trinity, 10, 9, 12 (PL 42, 980); René Descartes, Description of the Human Body and of All Its Functions, Part I, Preface (AT XI, 223). See also: Adam Krokiewicz, “GNŌTHI SEAUTON - poznaj siebie!", Meander 3-4/07 (2002): 197-210; Joanna Usakiewicz, $Z$ miłości do rozumu. O etyce Arnolda Geulincxa (1624-1669) (Białystok: Wydawnictwo Uniwersytetu w Białymstoku, 2010), 49-58.

11 Zgłębienie najwyższych względów swej istoty, [które] jest skutkiem rozmowy z sobą, [które] jest wewnętrznym namysłem; Ziemięcka, "Myśli o filozofii”: 409.

12 Noli foras ire, in teispum redi; in interiore homine habitata veritas; Augustine of Hippo, On True Religion, 39, 72 (PL 34, 154).

13 Uchwycenie głosu wewnętrznego; Ziemięcka, "Myśli o filozofii”: 411. 
etymology of the word. As Ziemięcka puts it, philosophy is "the love of the truth", ${ }^{14}$ and she understands love in a purely Platonic way: as the desire for what one does not have. ${ }^{15}$ And that is her accusation towards the philosophy of German idealism: it appears to be "total knowledge of the truth", ${ }^{16}$ but no longer it is the love of it.

Now, as the analysed text is an expression of a critical assessment of Hegel's thought, I am to pay attention to the excerpts that contrast Ziemięcka's understanding of philosophy with Hegel's one. She writes: "Philosophy is a science that attempts to investigate the supreme metaphysical questions; it is a work of the individual reason's might. I say individual for, although I agree that a contemporary stance may influence a philosopher's thought, I do not think in line with Hegel that the science of philosophy is an expression of the developing Idea, that in spite of their knowledge, all the philosophers make subsequent bonds of one chain (...). The history of philosophy is not the history of one Idea that continues through ages, but rather it is the history of studies by genial people in the area of metaphysical issues. The state of contemporary education, the location of states, or the general condition of an epoch often modify the thinker's viewpoint; it does not, however, stand for any relationship between the notions, but for a weakness of the reason that cannot resist the conditions of the times".17

Hence, Ziemięcka's dealing with philosophy is individual discovering the eternal and absolute truth, which is hampered by some external factors to the reason. She does not believe that discovering the truth is made in the course of historical and necessary development of philosophy and results from the

14 Miłość do prawdy; ibid., 414.

15 See Plato, Symposium, 200a.

16 Wiedza zupetna prawdy; ibid., 398. See also ibid., 414.

17 Filozofia jest nauka usiłująca zbadać najwyższe zagadnienia metafizyczne, jest dziełem potęgi rozumu indywidualnego, mówię: indywidualnego, bo chociaż uznaję, iż stanowisko wiekowe może wiele wplywać na myśl filozofa, nie mniemam jednak z Heglem, że nauka ta jest wyrazem rozwijającej się Idei, że wszyscy filozofowie mimo wiedzy swej, stanowiq kolejno ogniwa jednego tańcucha (...). Historia filozofii nie jest historia jednej Idei przez wieki się ciagnąca, sa to raczej dzieje badań genialnych ludzi w przedmiocie zagadnień metafizycznych. Oświata wspótczesna, położenie krain, stan ogólny epoki modyfikuja często widzenie mędrca, lecz to nie żadna pokrewność pojęć, tylko słabość rozumu, który warunkom czasu oprzeć się nie może; ibid., 407-408. 
totality of its actions. What Ziemięcka stresses in particular is the philosopher's individualism. She does so also in the next passage that I would like to quote, although it underlines other aspects of her understanding of philosophy. Ziemięcka writes: "Musing of individual spirits over their natures and their attitudes towards God is the most beautiful human privilege, common to all the eras, all the peoples, even all the levels of civilization". ${ }^{18}$ An unoriginal or even a trite statement? Not - if we bear in mind who has said it. Let us pay our attention to two issues.

First of all, those are woman's words. By her saying "a human being", she, as if, demands acknowledgement for her rights to be a philosopher. For ages, "a human being" meant only a man in philosophy, and only he was granted the full reason together with the possibility of abstract thinking. Women dealing with philosophy were but accepted as exceptions with "male spirit" or as curiosa that were more often ridiculed than admired. Ziemięcka speaks of a human as a being endowed with the reason whose gender is unimportant. It should be added here that she herself fell victim to some gender prejudice. It was the way that Ziemięcka and her Myśli o filozofii [Thoughts on Philosophy] were presented by Bronisław Ferdynand Trentowski (1808-1869) - one of the creators of the Polish national philosophy - who was viewed then as a philosophical celebrity. ${ }^{19}$ In his 1843 article entitled Listy naukowe. List drugi. O Floryanie Bochwicu, Antonim Bukatym i Eleonorze Ziemięckiej [Scientific Letters. The Second Letter. On Florian Bochwic, Antoni Bukaty, and Eleonora Ziemięcka], ${ }^{20}$ he expresses not only his condescension to a woman who dares to deal with philosophy but even his misogyny. Starting from a general statement, which according to him is proved by history, that "a woman is not created for philosophy and she appears to be simply ridiculous or even pitiful

18 Dumanie ducha indywidualnego nad swoja natura i swym stosunkiem do Boga stanowi najpiękniejszy przywilej człowieka, wspólny wszystkim wiekom, wszystkim ludom, wszystkim nawet stopniom cywilizacji; ibid., 408.

19 See, e.g., 700 lat myśli polskiej. Filozofia i myśl społeczna w latach 1831-1864, 216-283; entry: “Trentowski Bronisław Ferdynand”, in: Encyklopedia Filozofii Polskiej, vol. 2, 742-745.

${ }^{20}$ See Bronisław Ferdynand Trentowski, "Listy naukowe. List drugi. O Floryanie Bochwicu, Antonim Bukatym i Eleonorze Ziemięckiej”, Orędownik Naukowy. Pismo czasowe poświęcone literaturze, historyi, krytyce i nowinom literackim, no. 3 (1843), 17-21. 
creature in that field", ${ }^{21}$ he moves on to refusing a title of a philosopher to Ziemięcka and calling her "a foe of philosophy". ${ }^{22} \mathrm{He}$ even dares to compare Ziemięcka to a hummingbird that pecks a sleeping eagle only to be viewed as something original, ${ }^{23}$ or a little magpie that has seen philosophy from afar and talks about it to the audience. ${ }^{24}$ However, it is not these ornithological comparisons that show the worst side of their author. Trentowski refuses women their rights to deal with philosophy referring to the erroneous etymology of the Old-Polish word for a woman: niewiasta. He claims that the word means "the one who does not know [Polish: nie wie] anything, so the knowledge is not for her". ${ }^{25}$ Then, he adds that it is faith that is designed for a woman and her greatest happiness is in the prayer. However, even such an opponent of women in philosophy has to admit that Ziemięcka knows the German philosophy "and, as it seems, from original sources". ${ }^{26}$

Let us come back to Ziemięcka's words and pay our attention to the second issue. The words were uttered by a Polish woman in the times when Poles were deprived of a sovereign country, when they started their fight for preserving their own identity in various areas and strived for regaining their independence. Two uprisings took place within Ziemięcka's life: the November Uprising of 1830 and the January Uprising of 1863 . The text was written between them. As she writes of philosophy as something common to all the peoples, she seems to assert the Poles rights. As a woman, she is entitled to deal with philosophy; as a Polish woman, she is entitled to live in an independent Polish country: both those entitlements appertain to her by nature for a woman is a human being no less than a man.

${ }^{21}$ Kobieta do filozofii niestworzona i że na tem polu okazuje się zwyczajnie śmieszną, a nawet godną litości istota; ibid., 17.

${ }^{22}$ Nieprzyjaciótka filozofi; ibid., 17.

${ }^{23}$ See ibid., 18.

${ }^{24}$ See ibid., 19.

25 Nic nie wie, czyli że nie dla niej wiedza; ibid., 19. It may be added here that the Polish word niewiasta most likely originates from Old Slavonic nevěsta that meant a woman introduced to a family as a wife of one of the family members, e.g. as a daughter-in-law, which meant that she was a person still unknown to the husband's family. See Wiesław Boryś, Słownik etymologiczny języka polskiego (Kraków: Wydawnictwo Literackie, 2005), 363.

${ }^{26}$ I to jak się zdaje, $z$ oryginatów; Trentowski, "Listy naukowe. List drugi. O Floryanie Bochwicu, Antonim Bukatym i Eleonorze Ziemięckiej”, 19. 
What is crucial to understand Ziemięcka's philosophy is the phrase: "the most beautiful human privilege". The word "privilege" may again be interpreted as a reference to long-lasting privileging of men in philosophy, which is therefore a woman's assertation for her rights to deal with the science. Ziemięcka relates this privilege to its proper reference, to a human being who, as a rational being, can philosophize and can take a rational reflection on the world. There is also the adjective in its superlative form: "the most beautiful". The privilege to philosophize is the most beautiful as it is philosophy that makes human beings the fullest humans: it makes the use their reasons, which define their essence; those are only philosophical considerations that are "the work and the merit of a human being" ${ }^{27}$ What completes the role of philosophy as "the most beautiful privilege" are the expressions that Ziemięcka uses: "dear right", ${ }^{28}$ "divine obligation", ${ }^{29}$ or "sweetness of philosophical musings". ${ }^{30}$

However, what is fundamental to understand the role and the essence of philosophy are Ziemięcka beliefs that, firstly, the reason is limited in its cognitive functions, secondly, that the value of a philosophical system results from its influence on morality. Limitations to the reason are defined by the fact that is it one of the powers of the human spirit. In her Myśli o filozofii [Thoughts on Philosophy], Ziemięcka lists and discusses, apart from the power of reasoning, the power of feeling and the unity of the human spirit. She assigns philosophy to the power of reasoning and to the power of feeling is, according to her, a source of art - poetry in particular. The unity of the spirit becomes visible in the state of a prophetic ecstasy related to religion. ${ }^{31}$ The reason, being only one of the spiritual powers, is incapable of encompassing and explaining the spirit as a whole. ${ }^{32}$ Thus, the reason may discover the truth within its own capabilities only. "Systematicity is in fact an objective of our cognition, but the powers of reason have defined borders not to be ever crossed. Hence, the system that is created by the reason only is to be but an expression of its power, a relative certainty, but its theoretical development

\footnotetext{
27 Dziełem i zasługa człowieka; Ziemięcka, "Myśli o filozofii": 409.

28 Drogie prawo; ibid., 408.

29 Święta powinność; ibid., 408.

30 Słodycz rozmyślań filozoficznych; ibid., 409.

31 See ibid., 420 and further.

32 See ibid., 415-416.
} 
is to be only a pretence of the truth, not the truth itself". ${ }^{33}$ The reason may discover the natural world; however, it is incapable of explaining its essence, similarly as it is not to discover the essence of God. A philosopher who relies on the reason only is, according to Ziemięcka, similar to a researcher who bases on one single animal bone to talk about a structure of the whole animal's body. ${ }^{34}$ Thus, it should be accepted that "philosophy as the work of the reason alone is the noble and beautiful art, yet limited by its nature - no struggle by human pride is to overcome those limits" ${ }^{35}$ Thus, for Ziemięcka, "what makes a condition of truth in philosophical research is, at first, rejecting any pride, desire, or fame (...)".36

Realizing and accepting the limitedness of the reason leads to accepting the revealed truths and the role of faith as a reinforcement of the reason by revealing the truths to humans that are unavailable to their reason: "Who has understood the limitations of the reason must necessarily be led to the conclusion that the human life is governed by other, higher rule that is independent of us (...)". ${ }^{37}$ There is nothing left to the human being than "to think thoroughly of themselves, to connect to the revealed faith in belief, as it is only in that connection that the truth is to be found! (...)" ${ }^{38}$ The real philosophers are characterized not only by their faith in their reasonable spirits, but also in immortality and in God. ${ }^{39}$

According to Ziemięcka, human beings, as God's creatures, set their aim at pursuing God: manifested by their moral acts in their worldly lives. Philosophy is to support them in that: "Philosophy is different to all other sciences,

33 Systematyczność stanowi w istocie dążenie naszego poznania, ale władza rozumu ma zakreślone granice, których nigdy nie przejdzie, systemat więc samym rozumem utworzony będzie tylko wyrazem jego potęgi, będzie względna pewnościa, a teoretyczne jego rozwinięcie tylko pozorem prawdy, nie sama prawda; ibid., 409.

34 See ibid., 416.

35 Filozofia jako dzieło samego rozumu jest sztuka szlachetna, piękna, lecz ograniczona z swej natury; żadne usiłowania pychy ludzkiej tych granic nie przejda; ibid., 416.

${ }^{36}$ Warunkiem prawdy w badaniach filozoficznych jest odrzucenie naprzód wszelkiej pychy, $\dot{z} a ̨ d z y, \operatorname{stawy}(. .$.$) ; ibid., 411$.

37 Ten, co pojął granice rozumu, musi koniecznie być naprowadzony na wniosek, że życiu ludzkości przewodniczy inna, wyższa, niezależąca od nas zasada (...); ibid., 392.

38 Pomyśleć gruntownie nad sobą, połaczyć się przekonaniem z objawionq wiara, bo tylko $w$ tem połączeniu znajdzie prawdę!; ibid., 404.

${ }^{39}$ See ibid., 408. 
as its aim is set much higher: together with religion, it accompanies us in our worldly pilgrimage, it is like a voice from the other world; it does not have a direct application: it does not make its narrators neither rich nor particularly famous; it indirectly makes the society better, but its aim disappears in the infinity of the existence: the individual spirit and its education make the main subject of its study" ${ }^{40}$ Hence, Ziemięcka's belief that the value of a philosophical system should be measured by its positive influence on morality.

Ziemięcka views philosophy as the most beautiful human vocation but, in fact, it concerns one of the spiritual powers only, as the human spirit expresses its rationality in philosophy, its emotionality in art, and its totality in faith. It is religion that makes a human being understand the most important truths, it "makes a human being detach from the worldliness, not count on science nor poetic delight, but follow the truth inside oneself" ${ }^{41}$ Such understanding of the essence, role, and place of philosophy led Ziemięcka to the formulation of her philosophical beliefs in the spirit of Christianity.

Ziemięcka stressed that philosophical thinking was the need of every human, regardless of gender, nation, place, or time - the need resulting from the rationality of a human being. She believed, however, that human reason had its cognitive limitations caused by human imperfectness. Those deficits of the reason, however, were supplemented by the revelation. In Ziemięcka's opinion, philosophy had a very precise task of co-acting with religion in moral perfecting the human being towards the eternal life. On a spiritual plane, she connected very strongly the reason and the faith defining their mutual relation and the necessity to complete each other in the process of human development. She was not original in her attempts to connect religious faith with philosophical thinking, and she did not go beyond the time and place that she lived in. However, her defence of the belief that mutual completion of the

40 Filozofia różni się w tym od wszelkich innych nauk, bo też cel jej daleko wyższy, ona razem $z$ religia towarzyszy nam w ziemskiej pielgrzymce, jest jakby głosem $z$ innego świata; wprost zastosowania tu nie ma, opowiadaczów swoich ani możnymi, ani koniecznie głośnymi nie czyni; pośrednio udoskonala społeczność, lecz cel jej ginie w nieskończoności bytu: duch indywidualny, jego wychowanie jest głównym przedmiotem jej badań; ibid., 411.

${ }^{41}$ Nakazuje człowiekowi odrywać się od ziemskości, nie rachować ani na naukę, ani na poetyczne zachwycenie, tylko wewnątrz siebie śledzić prawdę; ibid., 421. 
reason and the faith was not only the basis for the woman's dignity and her personal equality with the man, but also made the woman capable of creative philosophical thinking and gave her the right to work critically in the field of philosophy, was very innovative in the lands inhabited by Poles in the 19th century and opposed deeply rooted patriarchal beliefs on the woman's nature and her social role. And it may be added here that those views were deeply rooted not within the Poles only.

Translated by Jarosław Solmiński

\section{References}

PL - Patrologie cursus completus. Series Latina. 1844-1855. Ed. Jacques Paul Migne. Parisiis: Excudebat Migne.

700 lat myśli polskiej. Filozofia i myśl społeczna w latach 1831-1864. 1977. Warszawa: Państwowe Wydawnictwo Naukowe.

Błachnio Jan Ryszard. 1994. Idealizm niemiecki i filozofia narodowa w polskiej myśli chrześcijańskiej lat 1831-1863. Bydgoszcz: Wydawnictwo Uczelniane WSP w Bydgoszczy.

Błachnio Jan Ryszard. 1997. Poglady filozoficzne Eleonory Ziemięckiej na tle sporów ideowych połowy XIX wieku. Bydgoszcz: Wydawnictwo Uczelniane WSP w Bydgoszczy.

Boryś Wiesław. 2005. Słownik etymologiczny języka polskiego. Kraków: Wydawnictwo Literackie.

Cicero. 1967. Tusculanae disputationes, ed. Max Pohlenz. Stutgardiae. In Aedibus B.G. Teubneri.

Encyklopedia Filozofii Polskiej. 2011. Red. zbiorowa. Vol. 2. Lublin: Polskie Towarzystwo Tomasza z Akwinu.

Krokiewicz Adam. 2002. GNŌTHI SEAUTON - poznaj siebie!”. Meander 3-4/07: 197-210.

Makuch Damian Włodzimierz. 2018. "Przeciwko pozorom rozumu. Eleonora Ziemięcka i opozycje myśli nowoczesnej”. Kronos 3, 46: 227-257.

The Philosophical Writings of Descartes. 1985. Vol. 1, trans. John Cottingham, Robert Stoothoff, Dugald Murdoch. Cambridge: Cambridge University Press.

Plato. 1955-1957. Opera, ed. John Burnet. Oxonii: Scriptorum Classicorum Bibliotheca Oxoniensis. 
Samborska-Kukuć Dorota. 2019. “Z genealogii rodu i biografii Eleonory z Gagatkiewiczów Ziemięckiej”. Ruch Literacki LX 4, 355: 475-486.

Trentowski Bronisław Ferdynand. 1843. "Listy naukowe. List drugi. O Floryanie Bochwicu, Antonim Bukatym i Eleonorze Ziemięckiej". Orędownik Naukowy. Pismo czasowe poświęcone literaturze, historyi, krytyce i nowinom literackim 3: $17-21$.

Usakiewicz Joanna. 2010. Z miłości do rozumu. O etyce Arnolda Geulincxa (16241669). Białystok: Wydawnictwo Uniwersytetu w Białymstoku.

Ziemięcka Eleonora. 1841. "Myśli o filozofii". Biblioteka Warszawska. Pismo poświęcone naukom, sztukom i przemysłowi 2: 388-422.

Ziemięcka Eleonora. 1857. Zarysy filozofii katolickiej w czterech pogladach zawarte. Warszawa: S. Orgelbrand.

Ziemięcka Eleonora. 2018. “Myśli o filozofii”. Kronos 3, 46: 258-277. 